\title{
The ocean response to volcanic iron fertilisation after the eruption of Kasatochi volcano: a regional-scale biogeochemical ocean model study
}

\author{
A. Lindenthal ${ }^{1}$, B. Langmann ${ }^{1}$, J. Pätsch ${ }^{2}$, I. Lorkowski ${ }^{2}$, and M. Hort ${ }^{1}$ \\ ${ }^{1}$ Institute of Geophysics, KlimaCampus, University of Hamburg, Hamburg, Germany \\ ${ }^{2}$ Institute of Oceanography, KlimaCampus, University of Hamburg, Hamburg, Germany \\ Correspondence to: B. Langmann (baerbel.langmann@zmaw.de)
}

Received: 29 June 2012 - Published in Biogeosciences Discuss.: 26 July 2012

Revised: 18 April 2013 - Accepted: 8 May 2013 - Published: 5 June 2013

\begin{abstract}
In high-nutrient-low-chlorophyll regions, phytoplankton growth is limited by the availability of watersoluble iron. The eruption of Kasatochi volcano in August 2008 led to ash deposition into the iron-limited NE Pacific Ocean. Volcanic ash released iron upon contact with seawater and generated a massive phytoplankton bloom. Here we investigate this event with a one-dimensional ocean biogeochemical column model to illuminate the ocean response to iron fertilisation by volcanic ash. The results indicate that the added iron triggered a phytoplankton bloom in the summer of 2008. Associated with this bloom, macronutrient concentrations such as nitrate and silicate decline and zooplankton biomass is enhanced in the ocean mixed layer. The simulated development of the drawdown of carbon dioxide and increase of $\mathrm{pH}$ in surface seawater is in good agreement with available observations. Sensitivity studies with different supply dates of iron to the ocean emphasise the favourable oceanic conditions in the NE Pacific to generate massive phytoplankton blooms in particular during July and August in comparison to other months. By varying the amount of volcanic ash and associated bio-available iron supplied to the ocean, model results demonstrate that the NE Pacific Ocean has higher, but limited capabilities to consume $\mathrm{CO}_{2}$ after iron fertilisation than those observed after the volcanic eruption of Kasatochi.
\end{abstract}

\section{Introduction}

In "high-nutrient-low-chlorophyll" (HNLC) oceanic regions, like the Southern Ocean, the equatorial and north-east Pacific, macronutrient concentrations are usually high. Phytoplankton growth is, however, limited by the availability of water-soluble iron (Martin and Fitzwater, 1988). During wintertime the availability of sunlight represents another major limiting factor. Generally, mineral dust is assumed to represent the major external source of bio-available iron for the open ocean (e.g. Jickels et al., 2005). In addition, other external sources like volcanic ash as a carrier of bio-available iron have recently been identified (e.g. Frogner et al., 2001; Duggen et al., 2007; Jones and Gislason, 2008). After the eruption of Kasatochi volcano on the Aleutian Islands in August 2008, volcanic ash was deposited into the iron-limited oceanic NE Pacific where atmospheric and oceanic conditions were favourable to generate a massive phytoplankton bloom as observed by satellite instruments (Fig. 1) (Langmann et al., 2010a) and in situ measurements (Hamme et al., 2010; Lockwood et al., 2012). The physical-chemical mechanisms behind the processes contributing to bio-available iron production on volcanic ash surfaces in volcanic plumes, where the ash undergoes temperature regimes from about $1000^{\circ} \mathrm{C}$ to ambient temperature, are still largely unknown (Ayris and Delmelle, 2012). Therefore, laboratory leaching experiments provide the major information on the bioavailability of iron from volcanic ash (e.g. Duggen et al., 2007; Olgun et al., 2011). Although these experiments reveal a large variability of the release rate of bio-available iron from volcanic ash, they showed that iron bio-availability 


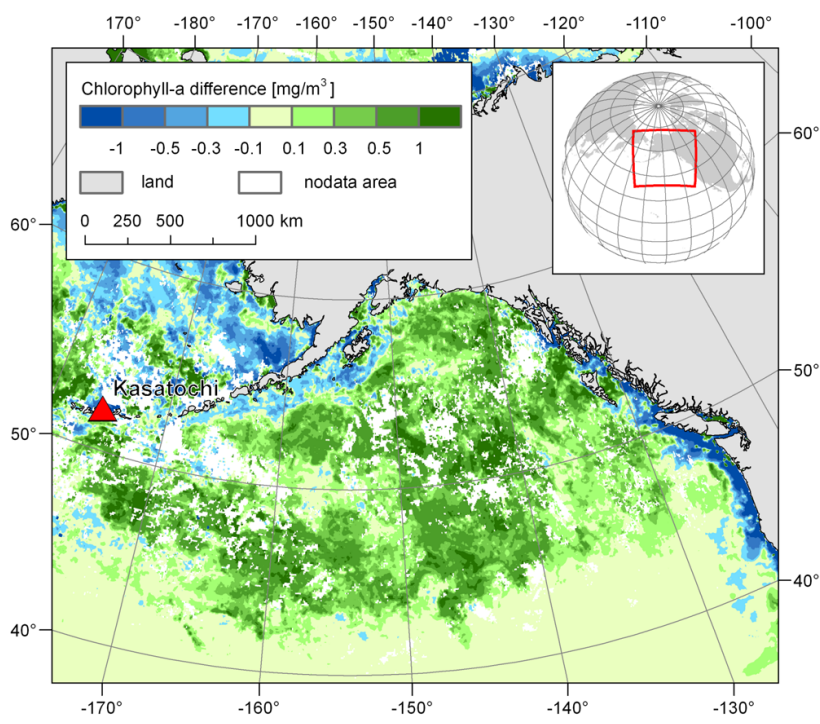

Fig. 1. MODIS Aqua chlorophyll $a\left[\mathrm{mg} \mathrm{m}^{-3}\right]$ in the NE Pacific: August 2008 monthly mean minus average monthly mean 20022007 (from Langmann et al., 2010a).

from volcanic ash surfaces is in the same range as that of mineral dust. But the amount of volcanic ash deposited into the surface ocean within a few days immediately after a volcanic eruption may exceed that of mineral dust by orders of magnitude (e.g. Gaiero et al., 2003), thus pointing to the need to improve our knowledge on the processes and impacts associated with volcanic ash fertilisation of the surface ocean.

We investigated the ocean fertilisation event after the eruption of Kasatochi in August 2008 with a regional-scale ocean biogeochemical model. As only limited in situ measurements are available, our modelling study may contribute to a better understanding of the NE Pacific biogeochemical response after being iron-fertilised by Kasatochi ash. In addition, this study may illuminate the potential connection between the huge number of sockeye salmon returning to the Fraser River in Canada in 2010 (Parsons and Whitney, 2012) and the ironfertilisation of the NE Pacific by Kasatochi ash in 2008. An improved understanding of such a connection is of considerable economic interest for the fishery industry. The volcanic eruption of Kasatochi is briefly summarised in Sect. 2. Section 3 describes the ocean biogeochemical model used for this study. Section 4 presents model results and comparisons with observations. Further model sensitivity experiments are discussed in Sect. 5 before conclusions and an outlook are given in Sect. 6.

\section{Kasatochi volcanic eruption}

The Kasatochi volcano $\left(52.17^{\circ} \mathrm{N}, 171.51^{\circ} \mathrm{W}\right)$ erupted on 7 August 2008. Three major explosive events occurred with eruption plumes rising to altitudes of about $15 \mathrm{~km}$

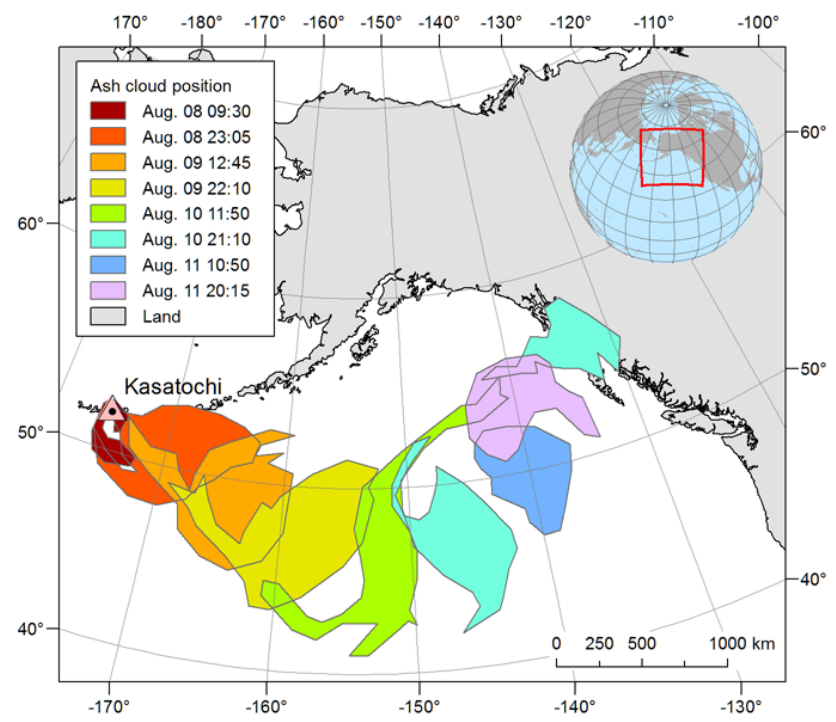

Fig. 2. Atmospheric dispersion of the Kasatochi ash cloud from 8 11 August 2008 based on MODIS level 1b data at 11 and $12 \mu \mathrm{m}$ using brightness temperature difference (BTD) (from Langmann et al., 2010a).

(Waythomas et al., 2010). The last explosive event on $8 \mathrm{Au}$ gust, which lasted for about $17 \mathrm{~h}$, contained the highest amount of volcanic ash (Waythomas et al., 2010). The ash cloud formed an anticlockwise spiral at altitudes between $9 \mathrm{~km}$ and $14 \mathrm{~km}$ and spread further eastward across the NE Pacific (Fig. 2) (Langmann et al., 2010a). Using an atmosphere-aerosol model, the release, dispersion and deposition of the Kasatochi ash was determined by Langmann et al. (2010b). Based on the modelled tephra fallout, they estimated the amount of iron supplied to the NE Pacific Ocean attached to the volcanic ash from Kasatochi. Assuming an ocean mixed layer depth of $30 \mathrm{~m}$ (Whitney and Freeland, 1999 ) and a release of $200 \mathrm{nmol} \mathrm{Fe}$ per gram volcanic ash (a typical value for subduction zone volcanoes; see Olgun et al., 2011), the resulting surface ocean iron concentration at Papa (Fig. 3a) is $0.3-0.7 \mathrm{nmol} \mathrm{L}^{-1}$. Associated daily ash fluxes to the ocean are displayed in Fig. 3b. Results from mesoscale iron enrichment experiments in the NE Pacific (Boyd et al., 2004) show that an increase of surface ocean iron concentrations by $1-2 \mathrm{nmol} \mathrm{L}^{-1}$ is sufficient for large diatoms to grow rapidly in this iron-limited region.

\section{Ocean biogeochemical model description}

The ECOHAM (Ecosystem Model, Hamburg) model, version 4 (e.g. Pätsch and Kühn, 2008; Lorkowski et al., 2012), was developed at the Institute of Oceanography at the University of Hamburg. It is a regional-scale three-dimensional ocean biogeochemistry model, coupled to the hydrodynamic model HAMSOM (Backhaus, 1985). ECOHAM has mainly been applied over the northwest European continental shelf 
(a) Iron $[\mathrm{nmol} / 1]$

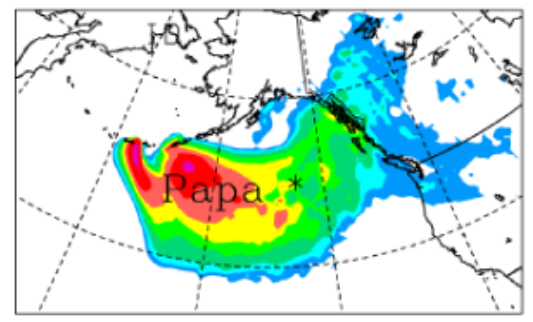

\begin{tabular}{ll|l|l|lll|lll} 
& 025 & .050 & .100 & .250 & .500 & 1.00 & 2.00 & 5.00
\end{tabular}

(b) Iron flux $[\mathrm{umol} / \mathrm{m} 2 / \mathrm{d}]$ Aug 8

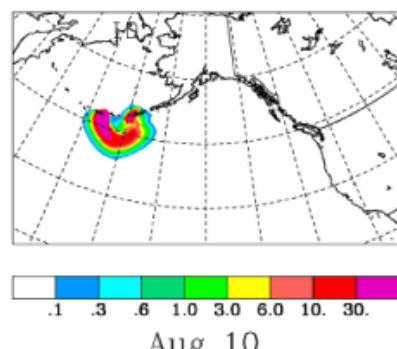

Aug 10
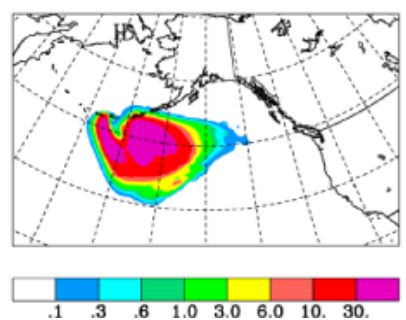

Aug 9
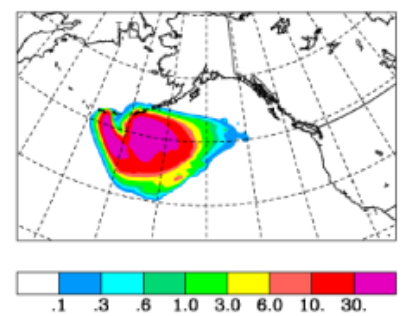

Aug 11
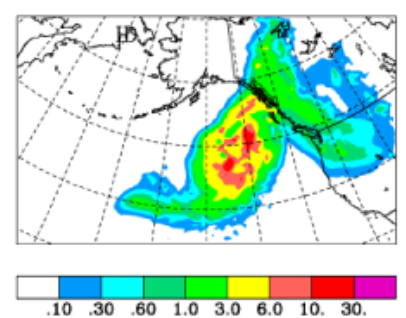

Fig. 3. (a) Modelled maximum available ocean mixed layer iron concentration after the eruption of Kasatochi in the NE Pacific Ocean from 8-15 August 2008 [nmol L ${ }^{-1}$ ] and (b) modelled daily fluxes of volcanic ash to the NE Pacific Ocean $\left[\mu \mathrm{mol} \mathrm{Fe} \mathrm{m}^{-2} \mathrm{~d}^{-1}\right]$. The location of station Papa is indicated in (a).

area. The model is able to simulate the biogeochemical cycles of carbon, oxygen, nitrogen, phosphate and silicate. To complete the carbon cycle a carbonate chemistry model is included. Pelagic prognostic variables in the water column are, for example, two kinds of phytoplankton (diatoms and flagellates), two kinds of zooplankton (meso- and microzooplankton), bacteria and two kinds of detritus (fast and slow sinking). Iron limitation does not play a role in this region.

For applications of ECOHAM in HNLC areas, an iron cycle model has been newly implemented, which considers the direct influence of iron addition to the euphotic zone on diatoms and flagellates (Fig. 4). The growth of phytoplankton is now limited, not only by light, nitrogen, phosphate, and in case of diatoms by silicate, but also by the availability of iron. Iron is recycled through the different detritus pools (Fig. 4). Due to the influence on primary production, the

iron may also indirectly influence the zooplankton biomass as well as the resulting carbon dioxide concentration. In this model approach the assumption is made that all dissolved iron in the first metres of seawater is bio-available for phytoplankton uptake. The iron model equations and associated parameters are given in the appendix. For the model equations for macronutrients, we refer to Lorkowski et al. (2012). The parameterisation of biogeochemical iron dynamics used here is very similar to those in other currently applied threedimensional ocean biogeochemical models (e.g. Aumont et al., 2003; Denman et al., 2006; Gregg et al., 2003; Lancelot et al., 2000; Moore et al., 2004). Despite their simplicity, these iron parameterisations proved to be able to reproduce the main biogeochemical patterns of the ocean (Boyd and Ellwood, 2010).

Meteorological forcing data of cloud cover, precipitation, solar irradiation, near-surface relative humidity, temperature, wind speed and direction for the year 2008 are taken from the ECMWF analysis database (http://cera-www. dkrz.de/WDCC/ui/Index.jsp) and have been interpolated to a $5^{\circ} \times 5^{\circ}$ latitude-longitude grid between $175.5-132.5^{\circ} \mathrm{W}$ and $40-60^{\circ} \mathrm{N}$ consisting of $10 \times 4$ grid cells, as the original purpose was to carry out 3-D model simulations. At this horizontal resolution it appears appropriate to neglect horizontal advection and diffusion, in particular as the focus of this study is on the summer months, when wind speed is considerably lower compared to the rest of the year (Whitney and Freeland, 1999). The coarse model resolution, however, leads to instabilities at the boundaries, so that we decided to carry out 1-D column model simulations. Therefore, the results presented in the manuscript are representative for a $5^{\circ} \times 5^{\circ}$ area from $145-150^{\circ} \mathrm{W}$ and $47.5-52.5^{\circ} \mathrm{N}$, including the location of the station Papa in the middle of the eastern edge.

We assume initial macronutrient concentrations in the surface water based on climatological means of the WOCE database in the NE Pacific Ocean (http://www. nodc.noaa.gov/OC5/SELECT/woaselect/woaselect.html): $14.6 \mu \mathrm{mol} \mathrm{N} \mathrm{L}^{-1}$ for nitrate, $1.3 \mu \mathrm{mol} \mathrm{PL} \mathrm{P}^{-1}$ for phosphate, $22.0 \mu \mathrm{mol} \mathrm{S} \mathrm{L}{ }^{-1}$ for silicate and $32.6 \mathrm{psu}$ for the salinity. For the initialisation of iron, we assume a concentration of $0.07 \mathrm{nmol} \mathrm{Fe} \mathrm{L}^{-1}$ in the upper $150 \mathrm{~m}$ of the ocean and a concentration of $0.4 \mathrm{nmol} \mathrm{Fe} \mathrm{L}^{-1}$ below the surface layer based on Aumont et al. (2003). Half-saturation constants of iron for diatoms $\left(0.12 \mathrm{nmol} \mathrm{Fe} \mathrm{L}^{-1}\right)$ and flagellates $\left(0.02 \mathrm{nmol} \mathrm{Fe} \mathrm{L}^{-1}\right)$ are slightly below the values of Denman et al. (2006), who carried out model simulations during the SERIES fertilisation experiments in the NE Pacific. The maximum growth rate of diatoms and flagellates is defined as $1.1 \mathrm{~d}^{-1}$ and $0.8 \mathrm{~d}^{-1}$, respectively. The grazing pressure of microzooplankton on flagellates is given by the maximum ingestion rate of $1.2 \mathrm{~d}^{-1}$. In order to damp growth during the cold seasons, the $Q 10$-value of diatoms, determining the temperature dependency of the uptake, is set to 3.0 (Berges et al., 2002). This factor determines the amount by which growth increases for every 10-degree rise in temperature. 


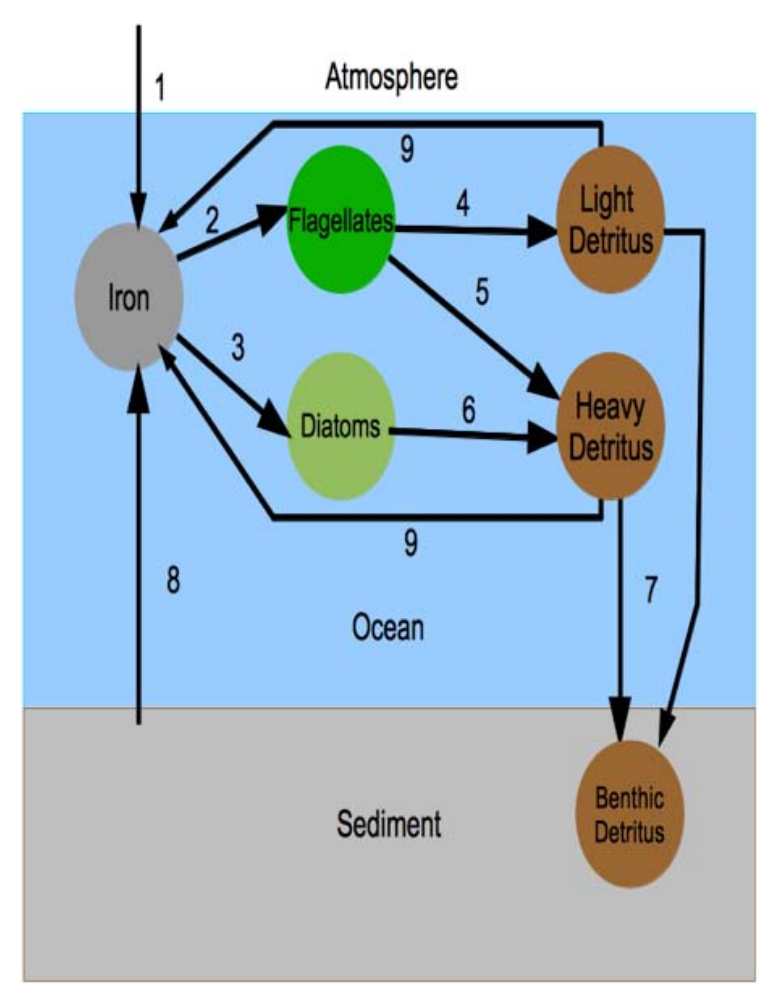

Fig. 4. Iron cycle in ECOHAM: (1) atmospheric iron deposition, (2) consumption of iron by flagellates, (3) consumption of iron by diatoms, $(4,5,6)$ mortality and egestion, (7) sinking of detritus in the water column, (8) benthic remineralisation, and (9) pelagic remineralisation.

The $\mathrm{C}: \mathrm{Fe}$ ratio $(=400000)$ in phytoplankton is defined according to Cassar et al. (2007).

We focus here on one-dimensional column applications around the buoy Papa $\left(50^{\circ} \mathrm{N}, 145^{\circ} \mathrm{W}\right)$. The water column is subdivided into 24 vertical layers of increasing thickness with depth, with the upper $50 \mathrm{~m}$ consisting of eight layers of $5 \mathrm{~m}$ depth and an upper layer of $10 \mathrm{~m}$ depth. The annual cycle of surface temperature, salinity and the mixed layer depth is prescribed according to data from Whitney and Freeland (1999). Below the mixed layer, vertical diffusion coefficients are set to $0.134 \times 10^{-5} \mathrm{~m}^{2} \mathrm{~s}^{-1}$. They gradually increase in the mixed layer, until a maximum of $0.028 \mathrm{~m}^{2} \mathrm{~s}^{-1}$ is reached close to the surface. To avoid too strong jumps between the months, the prescribed monthly mixed layer depths based on Whitney and Freeland (1999) are overlain by a short period sinusoidal "noise" with an amplitude of $10 \mathrm{~m}$. During the last 15 days of the year, the mixed layer depth is enlarged by $60 \mathrm{~m}$ to a total depth of $170 \mathrm{~m}$ in order to introduce nutrients from below. Based on Gregg et al. (2003), a background atmospheric deposition flux of $4.5 \mathrm{nmol} \mathrm{Fe} \mathrm{m}{ }^{-2} \mathrm{~d}^{-1}$ is added to the model, because in the applied 1-D model setup the iron concentration in the column would be too depleted without it. The fertilisation experiment described in Section 4 assumes an iron input associated with volcanic ash of $7247 \mathrm{nmol} \mathrm{Fe} \mathrm{m}^{-2}$ at Papa within the three days of 9-11 August 2008. The model is run for two years, with the first year serving as spin-up time. The 1-D model is in quasiequilibrium after this one year, as simulation results for the third model year resemble those of the second year. It should be noted that, for a 1-D column model set-up with limited dynamical variability, quasi-equilibrium conditions are reached much faster than for a 3-D model set-up.

\section{Model results and comparison with observations}

The analysis of the ECOHAM model results focuses on the nutrient, phytoplankton, zooplankton, $\mathrm{CO}_{2}$ and $\mathrm{pH}$ development in the NE Pacific Ocean following the iron release from volcanic ash after the eruption of Kasatochi. We compare model results of simulations without and with iron fertilisation at the station Papa in the upper $63 \mathrm{~m}$ of the ocean. We note that we focus on the influence of iron released from volcanic ash on the biogeochemistry of the ocean.

Modelled phytoplankton growth at Papa without volcanic ash fertilisation, which is shown in Fig. 5 from January to December 2008 for total phytoplankton, diatoms and non-diatoms, exhibits low values $\left(<3 \mu \mathrm{mol} \mathrm{CL}^{-1}\right)$ all over the year but increased values $\left(\sim 5 \mu \mathrm{mol} \mathrm{CL}^{-1}\right)$ in $\mathrm{Au}-$ gust/September 2008 induced by shallower mixed layer depths and therefore greater light availability within the mixed layer. Upon iron deposition associated with volcanic ash deposition during 9-11 August, the summer bloom is considerably intensified, reaching more than $8 \mu \mathrm{molCL} \mathrm{CL}^{-1}$. This bloom, lasting for several weeks, consists mainly of diatoms, and it is therefore in good agreement with measurements (Langmann et al., 2010a; Hamme et al., 2010). Without iron deposition, phytoplankton concentration remains at about $4 \mu \mathrm{mol} \mathrm{CL^{-1 }}$ during late summer/early autumn.

The comparison between observed Chl $a$ concentrations around Papa (MODIS monthly averaged data between 48 $56^{\circ} \mathrm{N}$ and $136-150^{\circ} \mathrm{W}$ ) for 2007 and 2008 (Hamme et al., 2010) shows reasonable agreement with the simulated concentrations for the 2008 undisturbed and 2008 disturbed scenario, respectively (Fig. 6). Applying a ratio of $\mathrm{C}: \mathrm{Chl}=120$ (Marchetti et al., 2007), the chlorophyll concentration was calculated diagnostically from the phytoplankton carbon content. The difference of maxima between the disturbed and undisturbed case is about $0.5 \mathrm{mg} \mathrm{Chl} \mathrm{m}^{-3}$ for both the observations and the simulation. The simulated largest difference was 2 weeks later than the observed ones. This might be caused by the prescribed climatologic mixed layer depth of $40 \mathrm{~m}$ in August. Observations of 2008 by the Argo fleet suggest a lower mixed layer depth of about $20 \mathrm{~m}$ (http://www.pac.dfo-mpo.gc.ca/science/ oceans/data/projects/argo/MLD/Mld2784.gif) and 25-30 m from glider data at Papa (Hamme et al., 2010).

Usually, macronutrients are available in high concentrations in the HNLC area of the NE Pacific Ocean with a 


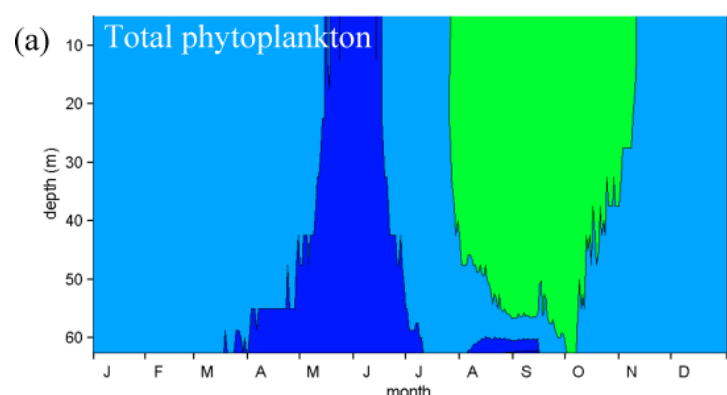

(b)

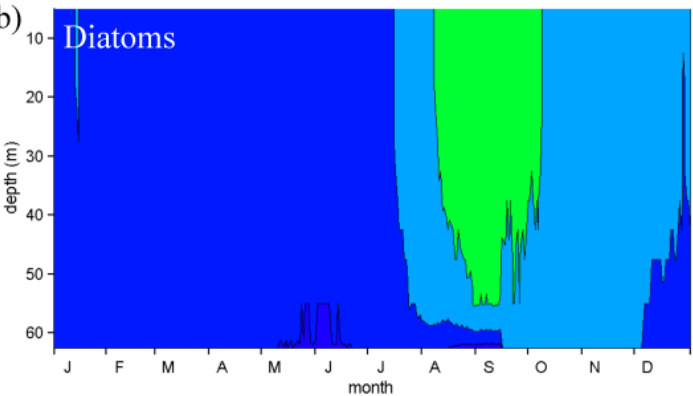

(c) ${ }_{10}$. Flagellates

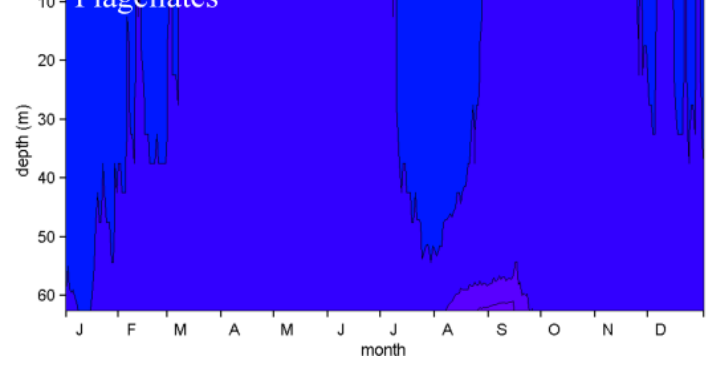

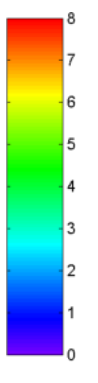
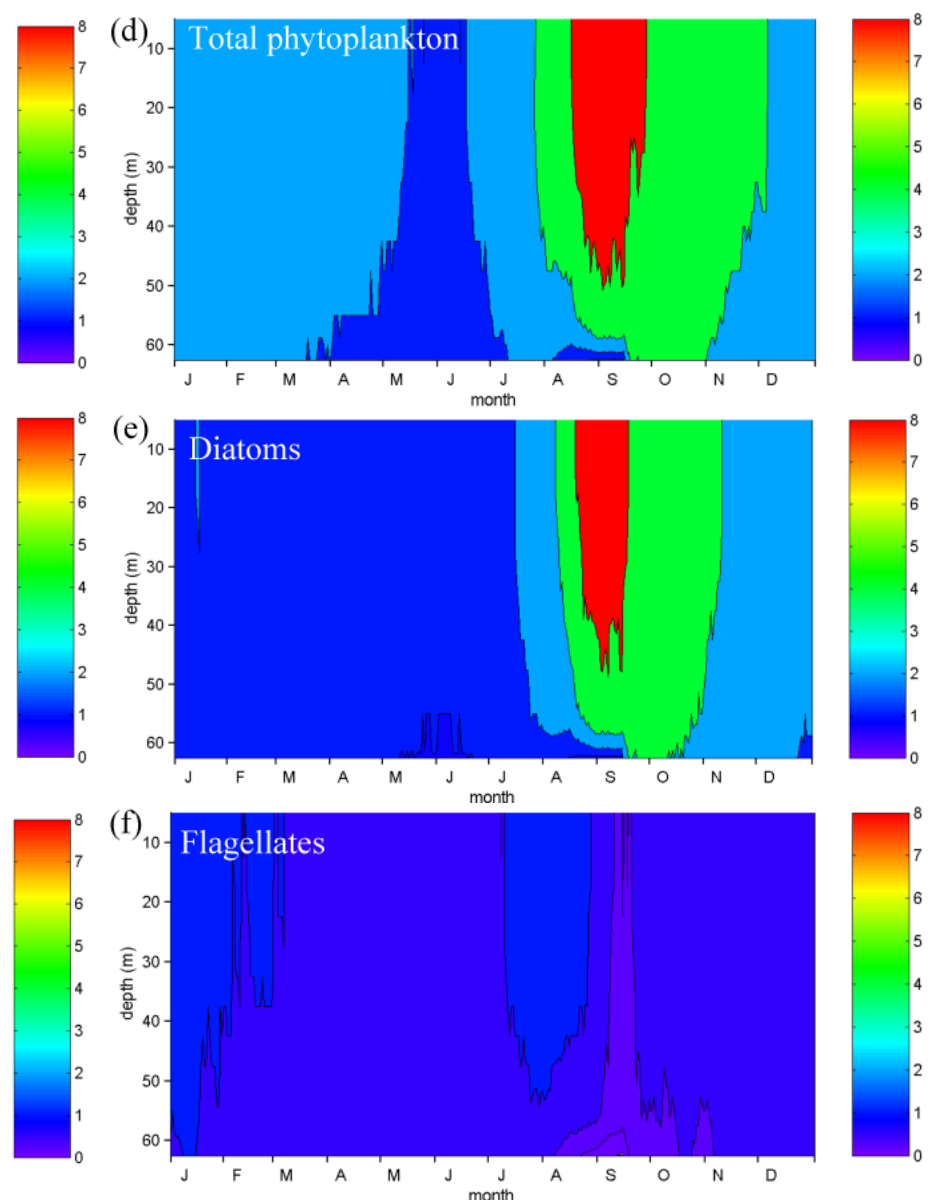

Fig. 5. Temporal evolution of the modelled vertical profile of $(\mathbf{a}, \mathbf{d})$ total phytoplankton, $(\mathbf{b}, \mathbf{e})$ diatoms and $(\mathbf{c}, \mathbf{f})$ non-diatoms in $\left[\mu m o l \mathrm{C}^{-1}\right]$ in the upper $63 \mathrm{~m}$ of the surface ocean at Papa during 2008, (a, b, c ) without and (d, e, f) with iron fertilisation in August 2008.

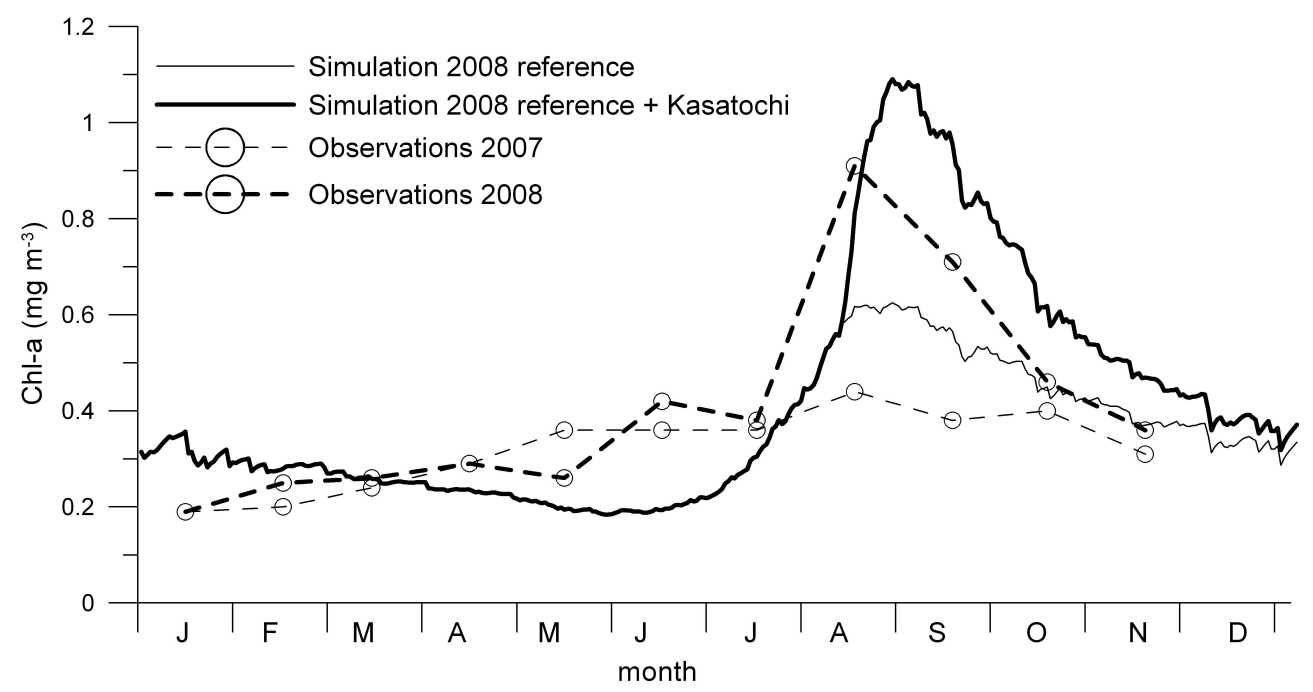

Fig. 6. Comparison of observed Chl $a$ concentrations at Papa for 2007/2008 (Hamme et al., 2010) and simulated Chl $a$ concentrations for 2008 with and without iron fertilisation in August 2008. 


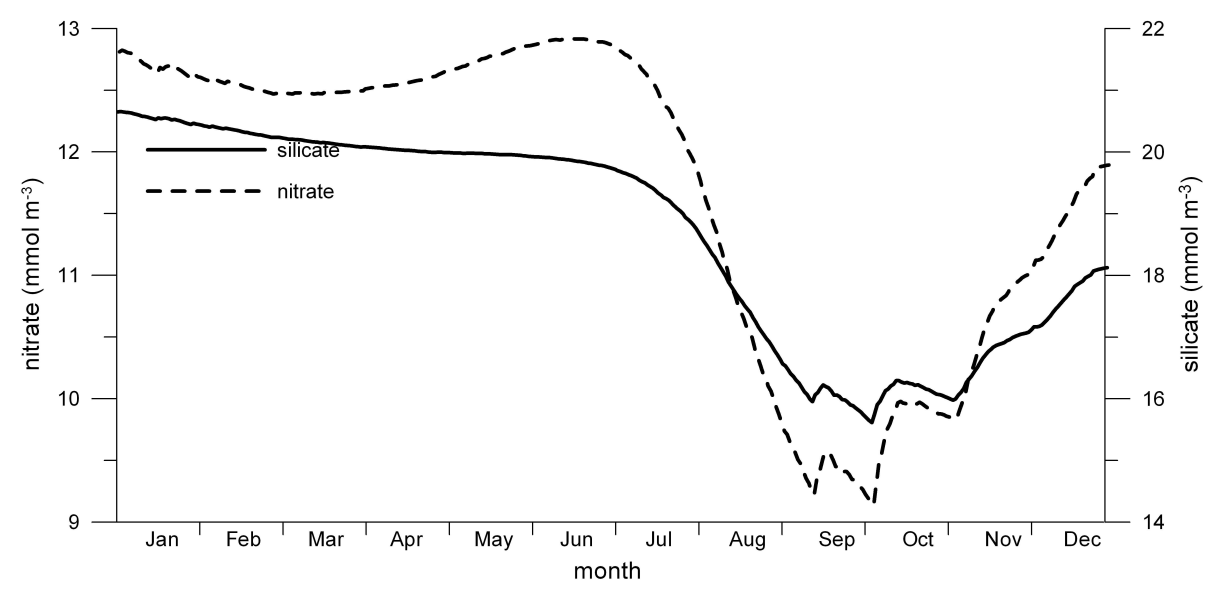

Fig. 7. Modelled annual cycle of surface nitrate and silicate without iron supply in August.

Table 1. Measured fluxes and concentrations under undisturbed and disturbed conditions around station Papa.

\begin{tabular}{|c|c|c|c|c|}
\hline & $\begin{array}{c}\text { Silicate }\left(\mu \mathrm{mol} \mathrm{L}{ }^{-1}\right) \\
\text { undisturbed/disturbed }\end{array}$ & $\begin{array}{c}\text { Nitrate }\left(\mu \mathrm{mol} \mathrm{L}^{-1}\right) \\
\text { undisturbed/disturbed }\end{array}$ & $\begin{array}{c}\mathrm{NPP}\left(\mathrm{mmol} \mathrm{C} \mathrm{m}{ }^{-2} \mathrm{~d}^{-1}\right) \\
\text { undisturbed/disturbed }\end{array}$ & $\begin{array}{c}\mathrm{NCP}\left(\mathrm{mmol} \mathrm{C} \mathrm{m}^{-2} \mathrm{~d}^{-1}\right) \\
\text { undisturbed/disturbed }\end{array}$ \\
\hline Measurements & $10-22^{\mathrm{a}, \mathrm{c}} / 5^{\mathrm{a}}, 5-12^{\mathrm{b}}$ & $9-13^{\mathrm{c}} / 2-10^{\mathrm{b}}$ & & $5-15^{\mathrm{a}} / 20-40^{\mathrm{a}}, 30-60^{\mathrm{b}}$ \\
\hline Model & 16-21/11-21 & $9-13 / 6-13$ & $5-16^{d} / 5-34$ & $2-11^{\mathrm{d}} / 2-25$ \\
\hline
\end{tabular}

regular decrease during summer and early autumn (Whitney and Freeland, 1999). During late autumn, winter and spring, the mixed layer concentrations are high due to efficient mixing with the deeper ocean layers (Fig. 7). The modelled annual cycle of nitrate and silicate reasonably reproduces the measurements (Whitney and Freeland, 1999), although silicate reaches the annual minimum with a delay of about two months and nitrate drawdown is a bit steeper than in the climatology (Fig. 7). With volcanic ash deposition in August 2008, when phytoplankton growth is no longer limited by the availability of iron (Fig. 8), macronutrient concentrations are further depleted (Fig. 9, Tab. 1). The maximum amount of iron in the upper level is $0.4 \mathrm{nmol} \mathrm{Fe} \mathrm{L}^{-1}$ on 10 August during the volcanic ash fertilisation. Atmospheric deposition makes up $8.9 \times 10^{3} \mathrm{nmol} \mathrm{Fe} \mathrm{m}^{-2} \mathrm{yr}^{-1}$ as shown in the temporal cumulative iron budget of the first $10 \mathrm{~m}$ of the ocean (Fig. 10). From this amount the volcanic eruption provided $7.2 \times 10^{3} \mathrm{nmol} \mathrm{Fe} \mathrm{m}^{-2} \mathrm{yr}^{-1}$. Turbulent mixing within the mixed layer is much faster in decreasing iron concentrations in the upper $10 \mathrm{~m}$ after the massive iron supply in $\mathrm{Au}-$ gust than the uptake of iron by diatoms. Hamme et al. (2010) and Lockwood et al. (2012) measured a distinct decrease in silicate and nitrate at Papa in August 2008 (Table 1). The model can reproduce this decrease in macronutrient concentration (Fig. 9). Release of silicate, phosphate, nitrate and ammonium from Kasatochi ash contributes in the nanomo- lar range (Olgun et al., 2012) and can thus be regarded as negligible. For the comparison of measured net community production (NCP) in Table 1, two snapshots are taken of the simulation results. The first one is from 1 August before the Kasatochi eruption, and the second one from 31 August about 2 weeks after the arrival of ash at Papa. For both runs, the undisturbed and the disturbed run, the net primary production NPP (gross production - autotroph respiration) and net community production NCP (NPP - heterotroph respiration) are equal for 1 August. The modelled depth-integrated value of NCP of the upper $10 \mathrm{~m}$ falls in the lower range of the values given in Table 1. It is interesting to observe that the NPP nearly doubles from the undisturbed to the disturbed case, while the NCP increase was about $250 \%$. This effect is caused in the model by an increase of bacterial respiration in the disturbed run in which bacterial activity is stimulated while at the same time they have to compete with phytoplankton for more exhausted inorganic nutrients.

Zooplankton biomass builds up with a delay of some weeks after the deposition of volcanic ash (Fig. 11), exceeding the background level by a factor of about 2 . According to Hamme et al. (2010) meso-zooplankton abundances were dominated by large copepods. Faecal pellets containing organic material feed mainly into the sinking detritus. High diatom abundances may also have increased export by increasing the density of sinking particles thereby slightly 

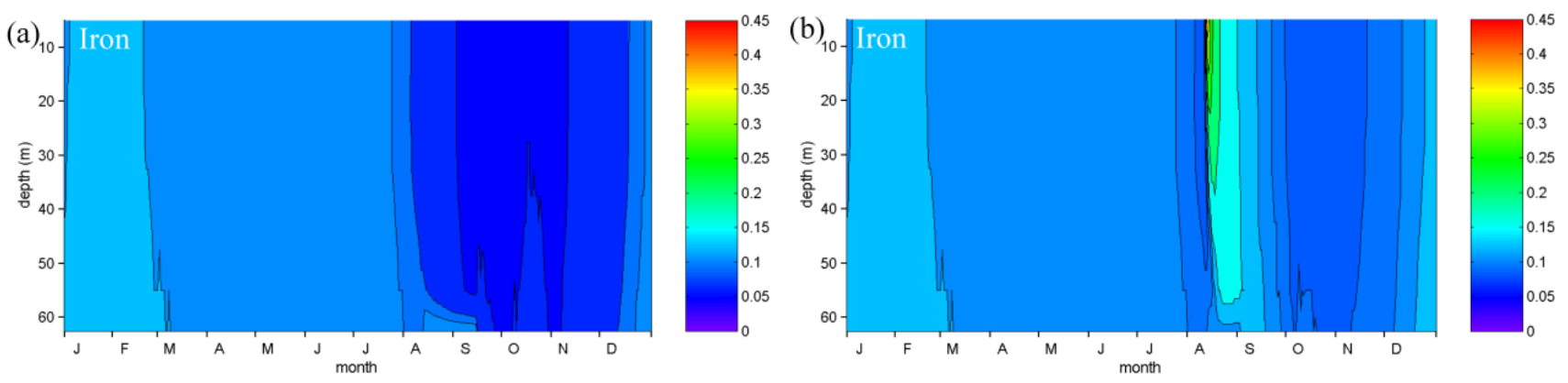

Fig. 8. Temporal evolution of the modelled vertical profile of dissolved iron in [nmol Fe $\mathrm{L}^{-1}$ ] in the upper $63 \mathrm{~m}$ of the surface ocean at Papa during 2008 (a) without and (b) with iron fertilisation in August 2008.
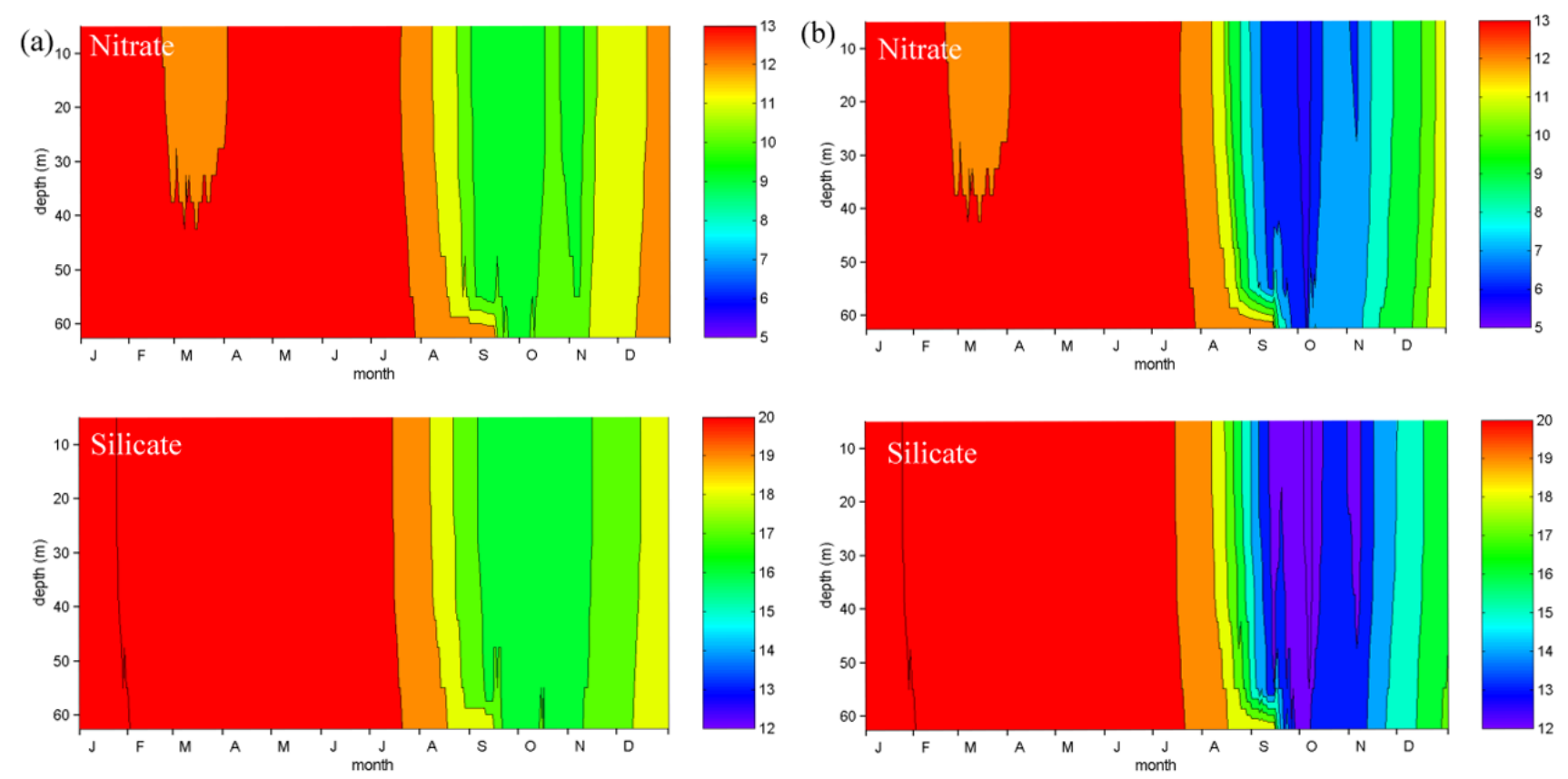

Fig. 9. Temporal evolution of the modelled vertical profile of nitrate $\left[\mu \mathrm{mol} \mathrm{N} \mathrm{L}{ }^{-1}\right]$ and silicate $\left[\mu \mathrm{mol} \mathrm{Si} \mathrm{L}^{-1}\right]$ in the upper $63 \mathrm{~m}$ of the surface ocean at Papa during 2008 (a) without and (b) with iron fertilisation in August 2008.

decreasing atmospheric $\mathrm{CO}_{2}$ by $\sim 0.01 \mathrm{PgC}$ (Hamme et al., 2010).

The simulated $\mathrm{pH}$ varies between 7.99 and 8.05 throughout the year at station Papa (Fig. 12). In August 2008, it increases from 8.01 to 8.06 after fertilisation with iron. This is in good agreement with in situ measurements by Hamme et al. (2010), who reported a measured $\mathrm{pH}$ increase of 0.06 from 8.08 to 8.14 . Increasing $\mathrm{pH}$ values and a decreasing $\mathrm{CO}_{2}$ partial pressure by about $40 \mathrm{ppm}$ in the surface seawater at Papa are caused by dissolved inorganic carbon consumption during primary production (Hamme et al., 2010). Fig. 13 shows the measured partial pressure of surface seawater $\left(p \mathrm{CO}_{2, \mathrm{Sw}}\right)$ during summer and autumn 2007 and 2008 (available from http://cdiac.ornl.gov/ftp/oceans/Moorings/Papa_145W 50N; Sabine et al., 2010) together with model simulation results with and without iron deposition in August 2008. Dur- ing 2007 measured $p \mathrm{CO}_{2}$, Sw decreases slightly from July until October. In 2008 measured $p \mathrm{CO}_{2}$, Sw starts to decrease already in late July by $20 \mu$ atm followed by a further sudden decline mid-August. We associate the latter with iron supply from Kasatochi ash. With iron deposition in $\mathrm{Au}-$ gust, a considerable decrease of $p \mathrm{CO}_{2, \mathrm{SW}}$ is simulated by the model, which is in good agreement with the measurements, although modelled $\mathrm{CO}_{2}$ concentrations decrease less steeply and the model shows an offset of about $25 \mu \mathrm{atm}$. The lower deviation and the slower decrease in the simulation after the eruption can be explained by the assumed climatologic mixed layer depth of $40 \mathrm{~m}$ in August, which is about 1.6-2 times larger than the situation in 2008 shows (Hamme et al., 2010; http://www.pac.dfo-mpo.gc.ca/science/oceans/ data/projects/argo/MLD/Mld2784.gif). Further discussion of potential reasons for the differences is presented in Sect. 5 . 


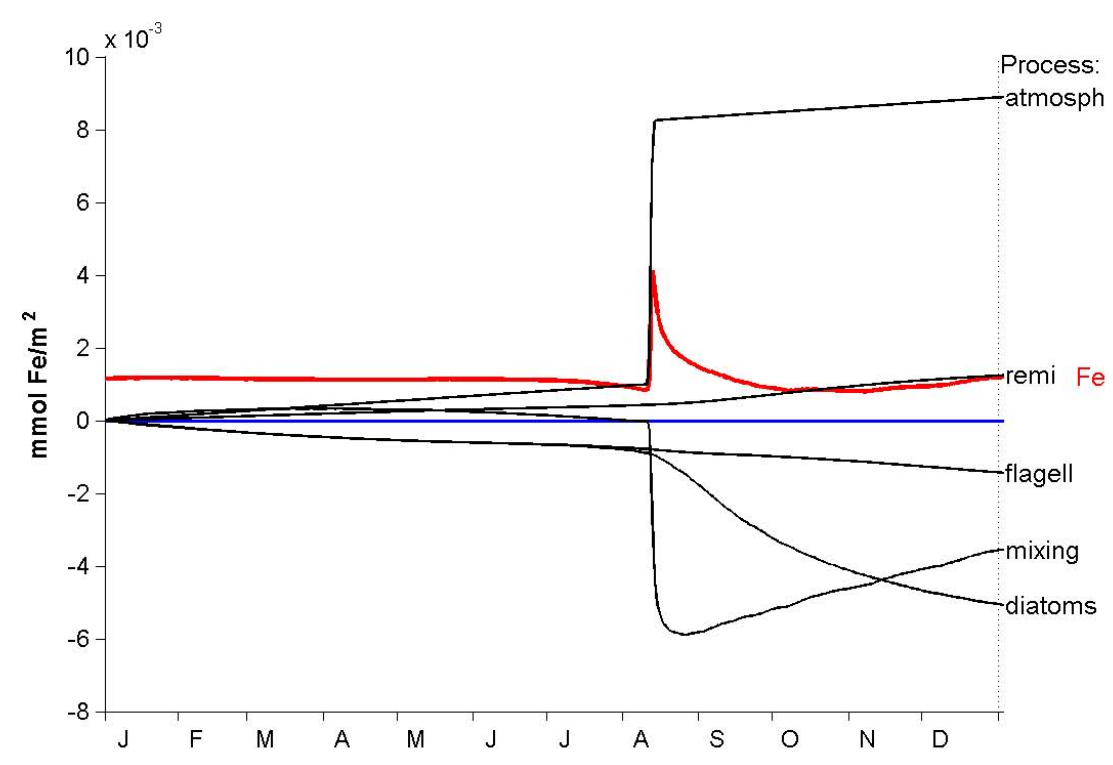

Fig. 10. Temporal cumulative iron budget $(0-10 \mathrm{~m})$ at Papa with iron fertilisation in August 2008. "Fe": iron amount, and the temporal cumulative fluxes "mixing": vertical mixing; "diatoms": uptake by diatoms; "flagell": uptake by non-diatoms; "atmosph": atmospheric input due to dust deposition and ash deposition; "remi": pelagic remineralisation.

Altogether ECOHAM model results show that volcanic ash can stimulate algae blooms in surface ocean waters in HNLC regions of the NE Pacific Ocean. Soluble iron released from volcanic ash reacts as a key micronutrient for phytoplankton growth.

\section{Model sensitivity studies and discussions}

Two kinds of sensitivity studies were carried out to investigate the influence of (a) different supply dates of iron to the ocean and (b) varying amounts of volcanic ash and associated bio-available iron deposition into the ocean.

\subsection{Timing}

This sensitivity study aims to illuminate the influence of the supply date of iron to the ocean on phytoplankton growth. The sensitivity study is conducted to investigate the general dependency on the time of the year of any volcanic eruption with volcanic ash deposition over the NE Pacific to fertilise the surface ocean. The sensitivity study is not conducted because of the uncertainty in the exact timing of the ash deposition from Kasatochi, which is of the order of a day only. Therefore the same amount of iron as in the standard experiment is deposited during the same number of days as in the standard experiment, but instead of August, in different months (Fig. 14).

As expected, the response of phytoplankton concentration in the surface ocean to iron supply is negligible during the months of November to June. During wintertime the availability of sunlight represents the major limiting factor for phytoplankton growth. In addition, the depth of the mixed layer of more than $100 \mathrm{~m}$ from November to June (Whitney and Freeland, 1999) restricts phytoplankton growth due to the higher supply requirements on iron than necessary for the shallow mixed layer from July until October. Therefore, iron supply during the summer months (June-September) generates the most massive phytoplankton blooms during the year. Nevertheless, also iron supply during the other months increases the summer bloom due to remineralisation processes. Here however, this aspect can be due to the application of a 1-D column model, where horizontal transport processes are neglected and therefore should be interpreted with care and should be evaluated by three-dimensional model applications.

Altogether, this sensitivity study emphasises the ability of the NE Pacific Ocean to form considerable phytoplankton blooms in the open ocean during the summer months upon iron supply. It demonstrates that external iron supply to the open NE Pacific, in particular from volcanic eruptions, may stimulate also zooplankton growth - a food source for salmon - and thus salmon survival rates in their critical last two-year phase of their four-year life cycle in the open ocean. Comparing sockeye salmon return runs to the Fraser River over the last century (Larkin, 2010) with volcanic eruptions in this region illustrates that at least two other volcanic eruptions may be connected to increased salmon returns runs: Katmai in 1912 and Bezymianny in 1956. 

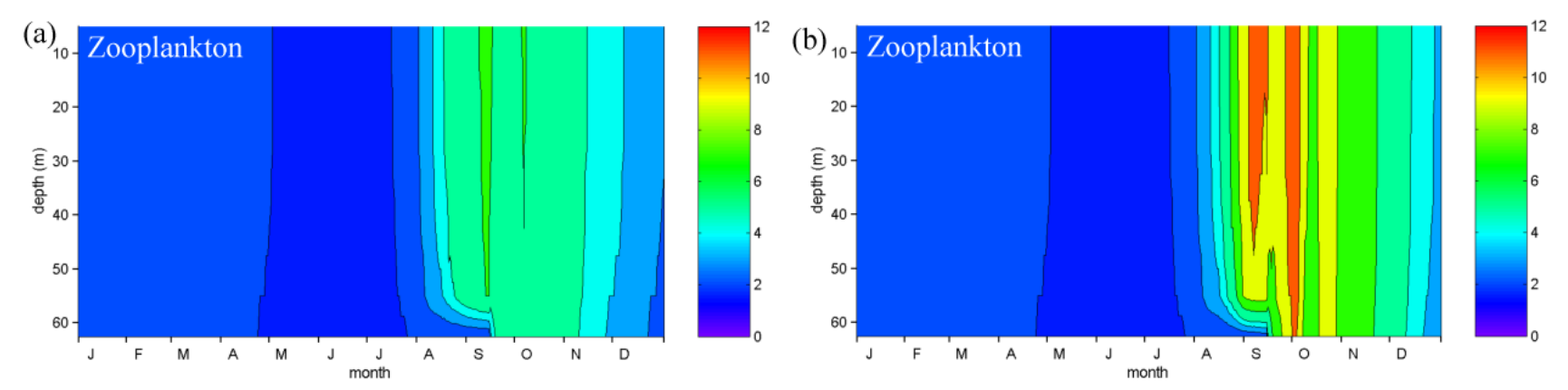

Fig. 11. Temporal evolution of the modelled vertical profile of zooplankton biomass $\left[\mu \mathrm{mol} \mathrm{C} \mathrm{L}^{-1}\right.$ ] in the upper $63 \mathrm{~m}$ of the surface ocean at Papa during 2008 (a) without and (b) with iron fertilisation in August 2008.

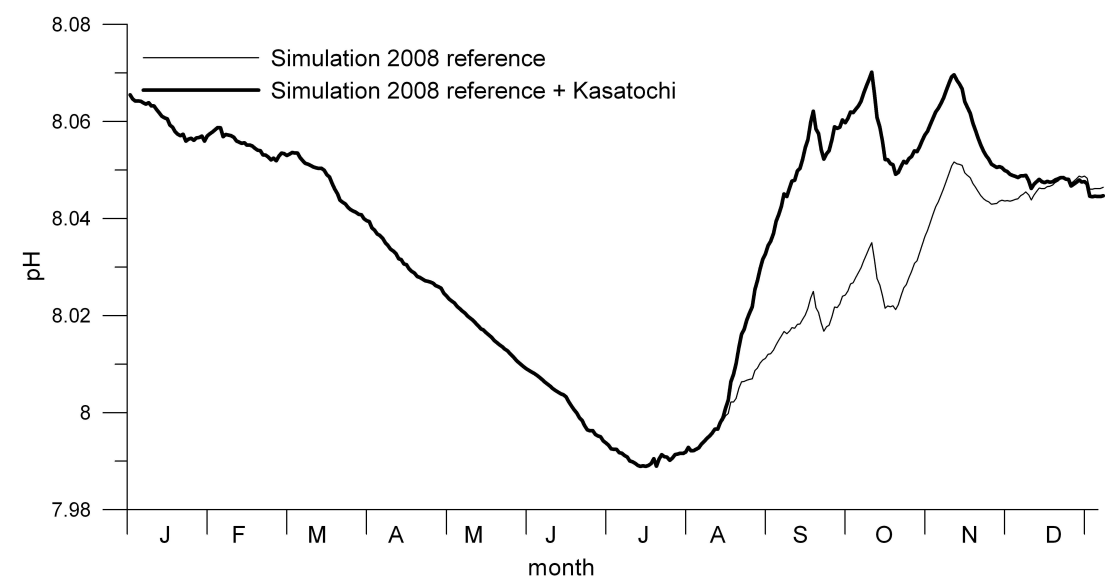

Fig. 12. Simulated $\mathrm{pH}$ in the upper $10 \mathrm{~m}$ of the ocean without (thin line) and with Fe (thick line) deposition in August 2008 at Papa.

\subsection{Amount of volcanic ash and associated bio-available iron deposition into the ocean}

Leaching experiments reveal a large variability in the release rate of iron from volcanic ash surfaces (Olgun et al., 2011). Only a few samples of Kasatochi ash are available showing lower iron release rates as assumed in our standard experiment (Olgun et al., 2012; Wang et al., 2010). As these samples consist of rather coarse ash, collected on a ship only about $13 \mathrm{~km}$ southwest of Kasatochi (Waythomas et al., 2010), the iron release rate might be not totally representative, as smaller ash particles with larger surface area per unit mass may carry larger amounts of bio-available iron. Another uncertainty is related to the deposition fluxes of volcanic ash to the ocean determined by dispersion and deposition modelling (Langmann et al., 2010b). Generally, volcanic ash dispersion and deposition models need a realistic characterisation of the ash source term of a volcanic eruption, e.g. erupted mass flux, ash cloud top height, vertical distribution of mass, ash particle size distribution and information of the temporal development of these quantities during an eruption. All this information is only partly available. In addition, atmospheric ash removal processes like gravitational settling, wet deposition and aggregation processes are not well constrained (e.g. Bonadonna and Folch, 2011), so that the end-product, the modelled flux of volcanic ash to the ocean at the station Papa, is subject of considerable uncertainty. Further uncertainties result from the complexity of the iron biogeochemical processes in the ocean, which are only partly understood: bio-availability of iron in the ocean water column is influenced by its chemical forms (speciation, redox state, ligands), biological cycling, and the different uptake strategies of the phytoplankton and bacteria communities (Boyd and Ellwood, 2010; Breitbarth et al., 2010). Iron co-limitations and interactions with other nutrients and trace metals affect the residence time of iron in the surface ocean, and ultimately the bioavailability of iron. Volcanic ash particles, for example, not only supply soluble iron, but can also act as scavengers for iron (Baker and Croot, 2010).

To investigate these uncertainties, we conducted a number of sensitivity studies with different iron supply fluxes to the ocean (Fig. 15). The ocean biogeochemistry is able to consume more $\mathrm{CO}_{2}$ (maximum drawdown $75 \mu \mathrm{atm}$ ) and to produce more phytoplankton when more iron is supplied than in the standard experiment. The more iron is supplied to the ocean, the faster is the $\mathrm{CO}_{2}$ decrease in surface seawater after fertilisation. The speed of drawdown is governed by the limitation factor of iron for diatoms: during days of 


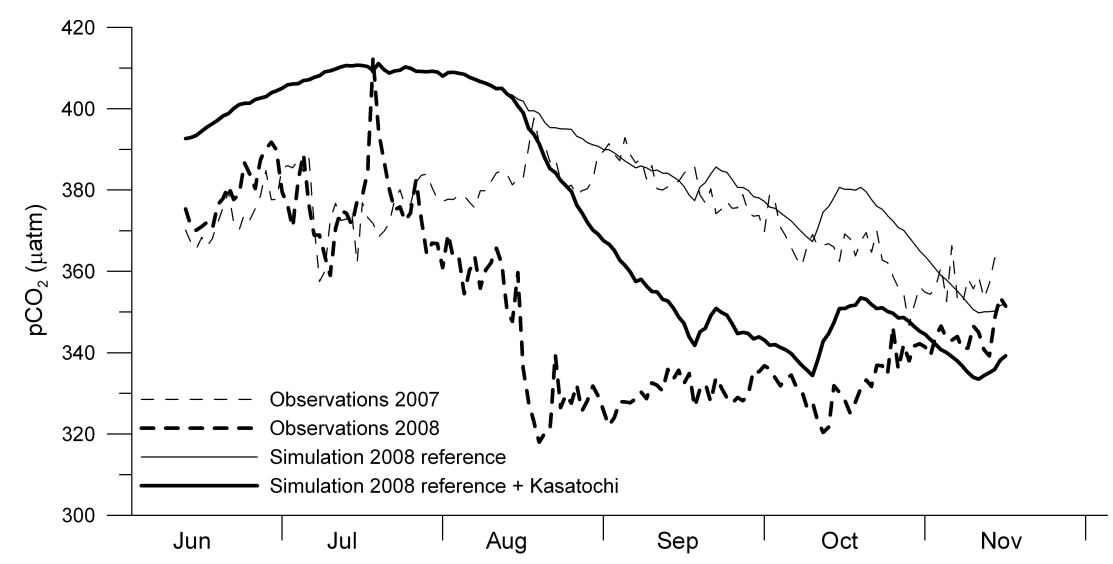

Fig. 13. Measured and simulated $p \mathrm{CO}_{2}, \mathrm{Sw}$ in surface seawater at Papa. Measurements are shown for the year 2007 and 2008 . Model results represent the year 2008 without and with considering iron deposition with volcanic ash fall.

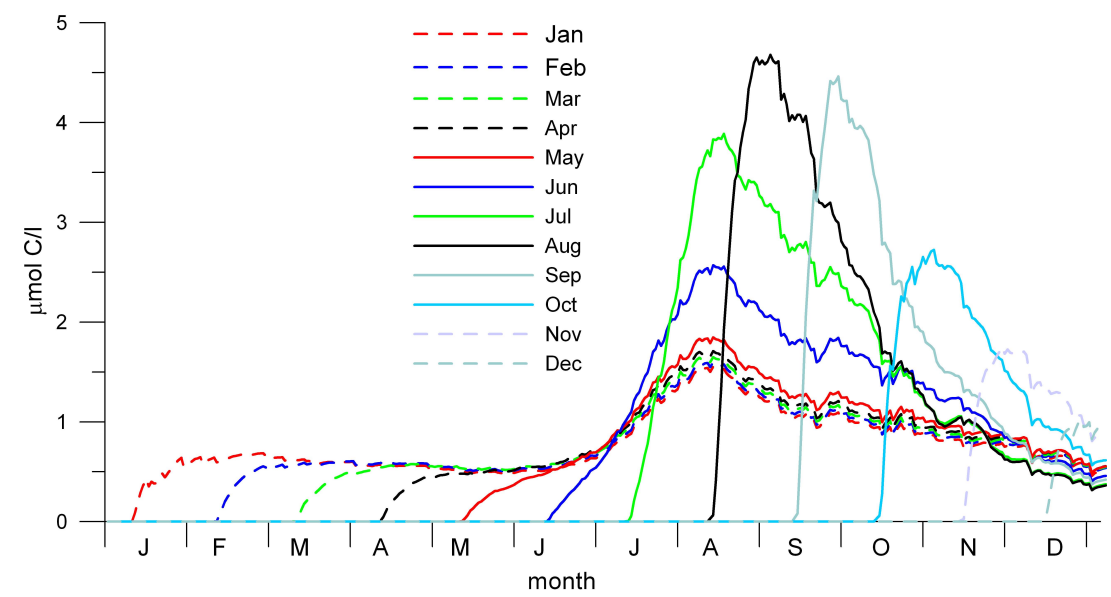

Fig. 14. Modelled increase in phytoplankton concentration at Papa in the upper $10 \mathrm{~m}$ of the ocean as function of different iron supply dates.

strongest iron input in the normal fertilisation run, this factor is about 0.5 ( 0.0 stands for total limitation; 1.0 corresponds to no limitation). In the fertilisation run with maximum iron input, the factor is 0.99 , which induces an increase of effective growth rate of about $200 \%$. Macronutrients like nitrate, phosphate and silicate limit further $\mathrm{CO}_{2}$ consumption when the iron supply rate is increased by a factor of more than 30 . In addition, the ocean mixed layer depth in the NE Pacific Ocean is restricted to $20-40 \mathrm{~m}$ during summer (Whitney and Freeland, 1999) so that the volume of water to be fertilised is a factor of 2.5-5 smaller than for example in the Southern Ocean (MLD $\sim 100 \mathrm{~m}$ ). Therefore, stronger phytoplankton blooms might be expected in the southern hemispheric summer in the Southern Ocean after iron supply by for example volcanic eruptions. To analyse if this is an effect of the one-dimensional column model simulation, further studies with three-dimensional ocean biogeochemical models will be necessary, which, in contrast to the one-dimensional column model simulations presented here, take into account horizontal advection and diffusion processes.

\section{Conclusions and outlook}

The first evidence of large-scale volcanic iron fertilisation of the surface ocean came from MODIS satellite data of chlorophyll $a$ after the eruption of Kasatochi in August 2008 (Langmann et al., 2010a). Meanwhile in situ measurements have become available to confirm the presence of the unusual large-scale phytoplankton bloom in the NE Pacific starting in August 2008 and persisting until about October 2008 (Hamme et al., 2010; Lockwood et al., 2012). The current study presents the first ocean biogeochemical model study of this event providing further insight into the nutrient, phytoplankton and zooplankton situation of the NE Pacific Ocean after fertilisation by soluble iron attached to volcanic ash. Increased zooplankton concentration after the iron fertilisation by volcanic ash in late summer 2008 underpins the speculations of Parsons and Whitney (2012) of increased survival rates of sockeye salmon in 2008 leading to record return runs to the Fraser River in 2010. The model simulations presented here demonstrate that optimal feeding conditions 


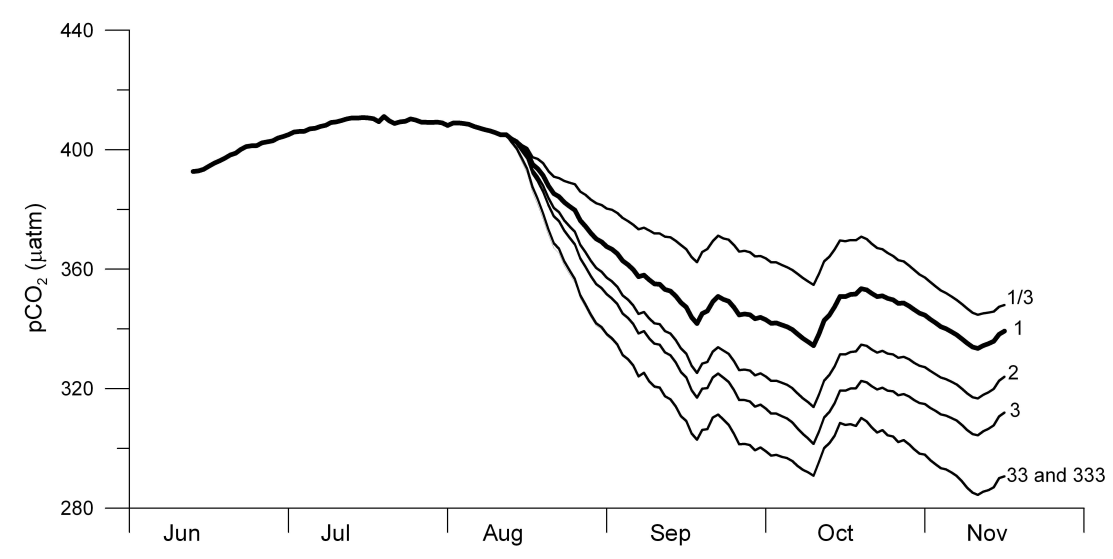

Fig. 15. Modelled $p \mathrm{CO}_{2}$, SW at Papa with different iron supply rates. The factors are related to the volcanic ash fertilisation run with factor of 1 which equals $7.25 \mu \mathrm{mol} \mathrm{m}{ }^{-2}$ (reference experiment), iron input factor of $1 / 3$ equals $2.42 \mu \mathrm{mol} \mathrm{m}^{-2}$, factor of 2 equals $14.5 \mu \mathrm{mol} \mathrm{m}{ }^{-2}$, factor of 3 equals $21.75 \mu \mathrm{mol} \mathrm{m}{ }^{-2}$, factor of 33 equals $239.25 \mu \mathrm{mol} \mathrm{m}^{-2}$, and factor of 333 equals $2414.25 \mu \mathrm{mol} \mathrm{m}{ }^{-2}$.

in the critical life stage of salmon were offered in the open ocean. However, the effect of volcanic ash on salmon populations is discussed controversially; for example, the analysis of McKinnell (2013) rejects the hypothesis of Parson and Whitney (2012).

Further studies on the amount of ash and iron deposited into the ocean after the eruption of Kasatochi as well as the assumed oceanic physical and biogeochemical conditions will be necessary to fully evaluate the presented model results. Therefore, three-dimensional model simulations on multi-year time scales are planned to further illuminate the fertilisation impact on atmospheric $\mathrm{CO}_{2}$ concentration by also analysing the biogeochemical processes in the deeper ocean.

To increase our current understanding of the volcanic ash fertilisation potential of the surface ocean, further progress of the iron processing in volcanic plumes and during long-range transport is necessary by conducting modeling studies and measurements in the field and laboratory. Until now, it is not well understood under which conditions the formation of bioavailable iron on volcanic ash surfaces is supported (Ayris and Delmelle, 2012). Leaching experiments of volcanic ash reveal a large variability in the release rate of bio-available iron from volcanic ashes (e.g. Olgun et al., 2011), emphasising the need for classifications, for example, according to the magma solid and gas composition and eruption conditions to better understand the impact of past and future volcanic eruptions on marine primary productivity and atmospheric $\mathrm{CO}_{2}$. It would be also wishful to assess the oceanic iron-fertilisation potential of volcanic ash for historical eruptions depending on the geographical volcano location, volcanic ash amount, macronutrient and micronutrient availability in the adjacent ocean areas and atmospheric conditions.

Although volcanic ash leaching experiments showed a large variability of the release rate of bio-available iron, they showed that iron bio-availability from volcanic ash surfaces is in the same range of that from mineral dust. Future studies should consider volcanic ash versus mineral dust ocean fertilisation and associated climate impacts (Langmann, 2013), as the amount of volcanic ash and bio-available iron attached to the ash surface deposited into the ocean during episodic large volcanic eruptions may exceed the annual dust flux by far. Gaiero et al. (2003) estimate that the iron deposition of the August 12 to 15 Mount Hudson volcanic eruption in Chile in 1991 is equivalent to $\sim 500 \mathrm{yr}$ of Patagonian iron dust fallout. In addition, fresh volcanic ash can be re-mobilised from tephra deposits, in particular in dry regions. Wilson et al. (2011), for example, report such post-eruption volcanic ash clouds after the eruption of Mount Hudson in Chile being transported over the Patagonian desert for several months after the eruption occurred. The ocean iron fertilisation potential by such re-mobilised ash clouds remains to be analysed.

\section{Appendix A}

Table A1. Iron-related state variables of the biological submodel, the acronyms used within the equations and their units.

\begin{tabular}{lll}
\hline Name & State variable & Unit \\
\hline n6f & iron & $\mathrm{mmol} \mathrm{Fe} \mathrm{m}^{-3}$ \\
p1f & diatoms-Fe & $\mathrm{mmol} \mathrm{Fe} \mathrm{m}^{-3}$ \\
p2f & flagellates-Fe & $\mathrm{mmol} \mathrm{Fe} \mathrm{m}^{-3}$ \\
d1f & detritus iron (slowly sinking) & $\mathrm{mmol} \mathrm{Fe} \mathrm{m}^{-3}$ \\
d2f & detritus iron (fast sinking) & $\mathrm{mmol} \mathrm{Fe} \mathrm{m}^{-3}$ \\
bof & benthic organic iron & $\mathrm{mmol} \mathrm{Fe} \mathrm{m}^{-2}$ \\
\hline
\end{tabular}


Table A2. The biogeochemical conservation equations of ECOHAM4 concerning iron. The equations for the state variables make use of fluxes between state variables; a flux from variable var1 to variable var2 is denoted by the acronym var1_var2. Transport tra(var1) includes vertical mixing mix $(\operatorname{var} 1)$; snk $\left(\mathrm{dxf}, w_{\mathrm{d} x}\right)$ indicates the change of $\mathrm{d} x \mathrm{f}(x=1,2)$ concentration due to sinking; water depth is $H$ and $k_{0}$ denotes the index of the deepest pelagic layer.

\begin{tabular}{|c|c|}
\hline State variables & Conservation equations \\
\hline iron & $\frac{\partial \mathrm{n} 6 \mathrm{f}}{\partial t}=-$ n6f_p1f - n6f_p2f + d1f_n6f + d2f_n6f + atm_n6f + bof_n6f $+\operatorname{tra}(n 6 f)$ \\
\hline diatoms-Fe & $\frac{\partial \mathrm{p} 1 \mathrm{f}}{\partial t}=$ n6f_p1f - p1f_d2f $+\operatorname{tra}(\mathrm{p} 1 \mathrm{f})$ \\
\hline flagellates-Fe & $\frac{\partial \mathrm{p} 2 \mathrm{f}}{\partial t}=\mathrm{n} 6 \mathrm{f} \_\mathrm{p} 2 \mathrm{f}-\mathrm{p} 2 \mathrm{f} \_\mathrm{d} 1 \mathrm{f}-\mathrm{p} 2 \mathrm{f} \_\mathrm{d} 2 \mathrm{f}+\operatorname{tra}(\mathrm{p} 2 \mathrm{f})$ \\
\hline detritus-Fe, slowly sinking & $\frac{\partial \mathrm{d} 1 \mathrm{f}}{\partial t}=\mathrm{p} 2 \mathrm{f} \_\mathrm{d} 1 \mathrm{f}-\mathrm{d} 1 \mathrm{f} \_n 6 \mathrm{f}-\operatorname{snk}\left(\mathrm{d} 1 \mathrm{f}, w_{\mathrm{d} 1}\right)+\operatorname{tra}(\mathrm{d} 1 \mathrm{f})$ \\
\hline detritus-Fe, fast sinking & $\frac{\partial \mathrm{d} 2 \mathrm{f}}{\partial t}=\mathrm{p} 1 \mathrm{f} \_\mathrm{d} 2 \mathrm{f}+\mathrm{p} 2 \mathrm{f} \_\mathrm{d} 2 \mathrm{f}-\mathrm{d} 2 \mathrm{f} \_n 6 \mathrm{f}-\mathrm{snk}\left(\mathrm{d} 2 \mathrm{f}, w_{\mathrm{d} 2}\right)+\operatorname{tra}(\mathrm{d} 2 \mathrm{f})$ \\
\hline benthic organic iron & $\frac{\partial \mathrm{bof}}{\partial t}=\left.\mathrm{d} z\left(k_{0}\right) \cdot \operatorname{snk}\left(\mathrm{d} 1 \mathrm{f}, w_{\mathrm{d} 1}\right)\right|_{z=H}+\left.\mathrm{d} z\left(k_{0}\right) \cdot \operatorname{snk}\left(\mathrm{d} 2 \mathrm{f}, w_{\mathrm{d} 2}\right)\right|_{z=H}-$ bof_n6f $\cdot \mathrm{d} z\left(k_{0}\right)$ \\
\hline
\end{tabular}

Table A3. Processes taken into account in the conservation equations; p1c - diatom carbon, p2c - flagellate carbon, phc - total phytoplankton carbon, dic - dissolved inorganic carbon, $T$ - temperature $\left({ }^{\circ} \mathrm{C}\right)$; grazing (pic_zxc) as defined in Lorkowski et al. (2012), with changed ingestion rates.

\begin{tabular}{|c|c|}
\hline Processes & Parameterisation \\
\hline iron fixation during diatom photosynthesis & n6f_plf $=\max \left(0\right.$, p $\left.1 f_{\text {uptake }}-(1-\operatorname{reg} 1) \cdot{\left.\text { p } 1 f_{\text {loss }}\right)}\right)$ \\
\hline iron fixation during flagellate photosynthesis & n6f_p2f $=\max \left(0\right.$, p2 $f_{\text {uptake }}-(1-$ reg 2$\left.) \cdot p 2 f_{\text {loss }}\right)$ \\
\hline diatom iron loss into fast sinking detritus & p1f_d2f $=h_{-}$p1f_d2f + reg $1 \cdot p 1 f_{\text {loss }}+\max \left(0,(1-\mathrm{reg} 1) \cdot p 1 f_{\text {loss }}-p 1 f_{\text {uptake }}\right)$ \\
\hline flagellate iron loss into slowly sinking detritus & p2f_d $1 \mathrm{f}=h \_$p2f_d $1 \mathrm{f}+\frac{1}{2} \cdot\left(\operatorname{reg} 2 \cdot \mathrm{p} 2 \mathrm{f}_{\text {loss }}+\max \left(0,(1-\mathrm{reg} 2) \cdot \mathrm{p} 2 \mathrm{f}_{\text {loss }}-\mathrm{p} 2 \mathrm{f}_{\text {uptake }}\right)\right)$ \\
\hline flagellate iron loss into fast sinking detritus & p2 $\mathrm{f}_{-} \mathrm{d} 2 \mathrm{f}=h_{-}$p2 $2 \mathrm{f}_{-} \mathrm{d} 2 \mathrm{f}+\frac{1}{2} \cdot\left(\operatorname{reg} 2 \cdot \mathrm{p} 2 \mathrm{f}_{\text {loss }}+\max \left(0,(1-\mathrm{reg} 2) \cdot \mathrm{p} 2 \mathrm{f}_{\text {loss }}-\mathrm{p} 2 \mathrm{f}_{\text {uptake }}\right)\right)$ \\
\hline uncorrected iron uptake by diatoms & p1f $f_{\text {uptake }}=$ dic_p1c_red $/ \mathrm{rcf}$ \\
\hline uncorrected iron uptake by flagellates & $\mathrm{p} 2 \mathrm{f}_{\text {uptake }}=$ dic_p2c_red/rcf \\
\hline carbon fixation by diatom photosynthesis & dic_p1c_red $=T_{\mathrm{fac} 1}(T) \cdot \mathrm{p} 1 \mathrm{c} \cdot F\left(I, v_{\mathrm{p} 1}, \mathrm{phc}\right) \cdot \lim _{\mathrm{p} 1}$ \\
\hline carbon fixation by flagellate photosynthesis & dic_p2c_red $=T_{\mathrm{fac} 2}(T) \cdot \mathrm{p} 2 \mathrm{c} \cdot F\left(I, v_{\mathrm{p} 2}, \mathrm{phc}\right) \cdot \lim _{\mathrm{p} 2}$ \\
\hline uncorrected iron loss by diatoms & $\mathrm{p}_{1} \mathrm{f}_{\text {loss }}=\left(\mathrm{p} 1 \mathrm{c} \_\mathrm{doc}+\mathrm{p} 1 \mathrm{c} \_z \mathrm{ze}\right) / \mathrm{rcf}$ \\
\hline uncorrected iron loss by flagellates & $\mathrm{p} 2 \mathrm{f}_{\text {loss }}=\left(\mathrm{p} 2 \mathrm{c} \_\mathrm{doc}+\mathrm{p} 2 \mathrm{c} \_\mathrm{zic}\right) / \mathrm{rcf}$ \\
\hline uncorrected iron loss by diatoms into detritus & $h \_p 1 f_{-} \mathrm{d} 2 \mathrm{f}=\left(\mathrm{p} 1 \mathrm{c} \_\mathrm{d} 1 \mathrm{c}+\mathrm{p} 1 \mathrm{c} \_\mathrm{d} 2 \mathrm{c}\right) / \mathrm{rcf}$ \\
\hline uncorrected iron loss by flagellates into detritus & $h \_\mathrm{p} 2 \mathrm{f} \_\mathrm{d} 1 \mathrm{f}=\mathrm{p} 2 \mathrm{c} \_\mathrm{d} 1 \mathrm{c} / \mathrm{rcf}$ \\
\hline uncorrected iron loss by flagellates into detritus & $h \_\mathrm{p} 2 \mathrm{f} \_\mathrm{d} 2 \mathrm{f}=\mathrm{p} 2 \mathrm{c} \_\mathrm{d} 2 \mathrm{c} / \mathrm{rcf}$ \\
\hline iron remineralisation of slowly sinking detritus & d1f_n6f $=T_{\mathrm{fac}}(T) \cdot \mu_{4} \cdot \mathrm{d} 1 \mathrm{f}$ \\
\hline iron remineralisation of fast sinking detritus & $\mathrm{d} 2 \mathrm{f} \_\mathrm{n} 6 \mathrm{f}=T_{\mathrm{fac}}(T) \cdot \mu_{5} \cdot \mathrm{d} 2 \mathrm{f}$ \\
\hline iron remineralisation of benthic organic iron & bof_n6f $=$ brf $\cdot$ bof $/ \mathrm{d} z\left(k_{0}\right)$ \\
\hline sinking of matter $X$ & $\operatorname{snk}(X, w)=w \cdot \frac{\partial X}{\partial z}$ \\
\hline vertical mixing of matter $X$ & $\operatorname{mix}(X)=\frac{\partial}{\partial z} A_{v} \cdot \frac{\partial X}{\partial z}$ \\
\hline
\end{tabular}


Table A4. Functions within the process parameterisations; limitation factors other than for iron in Lorkowski et al. (2012).

\begin{tabular}{ll}
\hline Name & Functions \\
\hline light-dependent growth rate & $F\left(I, v_{\mathrm{pi}}, \mathrm{phc}\right)=v_{\mathrm{pi}} \cdot \frac{I_{\mathrm{par}}(z)}{I_{\mathrm{opt}}} \cdot e^{1-\frac{I_{\mathrm{par}}(z)}{I_{\mathrm{opt}}}}$ with $z:$ actual depth $(i=1,2)$ \\
limitation factor diatom uptake & $\lim _{\mathrm{p} 1}=\min \left[\lim _{\mathrm{Fe}}^{1}, \lim _{\mathrm{N}}, \lim _{\mathrm{P}}, \lim _{\mathrm{Si}}\right]$ \\
limitation factor diatom iron & $\lim _{\mathrm{Fe}}^{1}=\frac{\mathrm{n} 6 \mathrm{f}}{K_{\mathrm{Fe}}^{1}+\mathrm{n} 6 \mathrm{f}}$ \\
limitation factor flagellate uptake & $\lim _{\mathrm{p} 2}=\min \left[\lim _{\mathrm{Fe}}^{2}, \lim _{\mathrm{N}}, \lim _{\mathrm{P}}\right]$ \\
limitation factor flagellate iron & $\lim _{\mathrm{Fe}}^{2}=\frac{\mathrm{n} 6 \mathrm{f}}{K_{\mathrm{Fe}}^{2}+\mathrm{n} 6 \mathrm{f}}$ \\
temperature factor & $T_{\mathrm{fac}}(T)=1.5^{\frac{T-T_{0}}{T_{0}}}$ with $T_{0}=10^{\circ} \mathrm{C}$ for the ecosystem metabolic rates \\
temperature factor diatoms & $T_{\mathrm{fac} 1}(T)=3.0^{\frac{T-T_{0}}{T_{0}}}$ with $T_{0}=10^{\circ} \mathrm{C}$ \\
temperature factor flagellates & $T_{\mathrm{fac} 2}(T)=1.5^{\frac{T-T_{0}}{T_{0}}}$ with $T_{0}=10^{\circ} \mathrm{C}$ \\
\hline
\end{tabular}

Table A5. Parameters and their values. All rate values are valid for $10^{\circ} \mathrm{C}$.

\begin{tabular}{|c|c|c|}
\hline Parameter & Unit & Value \\
\hline remineralisation rate of benthic organic iron & $d^{-1}$ & brf $=0.0333$ \\
\hline maximum ingestion rate of mesozooplankton (zec) & $d^{-1}$ & $g_{1}=0.4$ \\
\hline maximum ingestion rate of microzooplankton (zic) & $d^{-1}$ & $g_{2}=1.2$ \\
\hline half-saturation constant uptake of iron by diatoms & $\mathrm{mmol} \mathrm{Fe} \mathrm{m}^{-3}$ & $K_{\mathrm{Fe}}^{1}=0.00012$ \\
\hline half-saturation constant uptake of iron by flagellates & $\mathrm{mmol} \mathrm{Fe} \mathrm{m}^{-3}$ & $K_{\mathrm{Fe}}^{2}=0.00002$ \\
\hline breakdown rate of slowly sinking detritus & $d^{-1}$ & $\mu_{4}=0.12$ \\
\hline breakdown rate of fast sinking detritus & $d^{-1}$ & $\mu_{5}=0.10$ \\
\hline $\mathrm{C}: \mathrm{Fe}$ ratio of plankton & $\mathrm{mol} \mathrm{C} / \mathrm{mol} \mathrm{Fe}$ & $\mathrm{rcz}=400000$ \\
\hline factor for diatom iron compensation fluxes & & reg $1=0.5$ \\
\hline factor for flagellate iron compensation fluxes & & $\operatorname{reg} 2=0.5$ \\
\hline velocity of slowly sinking detritus & $\mathrm{md}^{-1}$ & $w_{\mathrm{d} 1}=0.4$ \\
\hline velocity of fast sinking detritus & $\mathrm{md}^{-1}$ & $w_{\mathrm{d} 2}=1.0$ \\
\hline
\end{tabular}

Acknowledgements. This work has been supported through the Cluster of Excellence "CliSAP" (EXC177), University of Hamburg, funded through the German Science Foundation (DFG). The authors thank the anonymous reviewers for their valuable comments on the manuscript.

\section{Edited by: C. Garbe}

B. Langmann has been funded by the German Science Foundation project LA 1485/2-1.

\section{References}

Aumont, O., Maier-Reimer, E., Blain, S., and Monfray, P.: An ecosystem model of the global ocean including $\mathrm{Fe}$, Si, P colimitations, Global Biogeochem. Cy., 17, 1060, doi:10.1029/2001GB001745, 2003.
Ayris, P. and Delmelle, P.: Volcanic and atmospheric controls on ash iron solubility: a review, Phys. Chem. Earth, 45-46, 103-112, JPCE-D-11-00132, 2012.

Backhaus, J. O.: A three-dimensional model for the simulation of shelf sea dynamics, Deutsche Hydrographische Zeitung, 38, 167-262, 1985.

Baker, A. R. and Croot, P. L.: Atmospheric and marine controls on aerosol iron solubility in seawater, Mar. Chem., 120, 4-13, 2010.

Berges, J. A., Varela, D. E., and Harrison, P. J.: Effects of temperature on growth rate, cell composition and nitrogen metabolism in the marine diatom Thalassiosira pseudonana (Bacillariophyceae), Mar. Ecol.-Progr. Ser., 225, 139-146, 2002.

Bonadonna, C. and Foch, A.: Ash Dispersal Forecast and Civil Aviation Workshop - Consensual Document, https://vhub.org/ resources/503, 2011.

Boyd, P. W. and Ellwood, M. J.: The biogeochemical cycle of iron in the ocean, Nat. Geosci., 3, 675-682, doi:10.1038/ngeo964, 2010.

Boyd, P. W., Law, C.S., Wong, C. S., Nojiri, Y., Tsuda, A., Levasseur, M., Takeda, S., Rivkin, R., Harrison, P. J., Strzepek, R., 
Gower, J., McKay, R. M., Abraham, E., Arychuk, M., BarwellClarke, J., Crawford, W., Crawford, D., Hale, M., Harada, K., Johnson, K., Kiyosawa, H., Kudo, I., Marchetti, A., Miller, W., Needoba, J., Nishioka, J., Ogawa, H., Page, J., Robert, M., Saito, H., Sastri, A., Sherry, N., Soutar, T., Sutherland, N., Taira, Y., Whitney, F., Wong, S.-K. E., and Yoshimura, T.: The decline and fate of an iron induced subarctic phytoplankton bloom, Nature, 428, 549-552, 2004.

Breitbarth, E., Achterberg, E. P., Ardelan, M. V., Baker, A. R., Bucciarelli, E., Chever, F., Croot, P. L., Duggen, S., Gledhill, M., Hassellöv, M., Hassler, C., Hoffmann, L. J., Hunter, K. A., Hutchins, D. A., Ingri, J., Jickells, T., Lohan, M. C., Nielsdóttir, M. C., Sarthou, G., Schoemann, V., Trapp, J. M., Turner, D. R., and Ye, Y.: Iron biogeochemistry across marine systems progress from the past decade, Biogeosciences, 7, 1075-1097, doi:10.5194/bg-7-1075-2010, 2010.

Cassar, N., Bender, M. L., Barnett, B. A., Fan, S., Moxim, W. J., Levy II, H., and Tilbrook, B.: The Southern Ocean biological response to Aeolian iron deposition, Science, 317, 1067-1070, doi:10.1126/science.1144602, 2007.

Denman, K. L., Christoph Voelker, C., Pena, M. A., and Rivkin, R. B.: Modelling the ecosystem response to iron fertilization in the subarctic NE Pacific: The influence of grazing, and $\mathrm{Si}$ and $\mathrm{N}$ cycling on $\mathrm{CO}_{2}$ drawdown, Deep-Sea Res. Pt. II, 53, 2327-2352, 2006.

Duggen, S., Croot, P., Schacht, U., and Hoffmann, L.: Subduction zone volcanic ash can fertilize the surface ocean and stimulate phytoplankton growth: Evidence from biogeochemical experiments and satellite data, Geophys. Res. Lett., 34, L01612, doi:10.1029/2006GL027522, 2007.

Frogner, P., Gislason, S. R., and Oskarsson, N.: Fertilising potential of volcanic ash in ocean surface water, Geology, 29, 487-490, 2001.

Gaiero, D. M., Probst, J. L., Depetris, P. J., Bidart, S. M., and Leleyter, L.: Iron and other transition metals in Patagonian riverborne and windborne materials: geochemical control and transport to the southern South Atlantic Ocean, Geochim. Cosmochim. Ac., 67, 3603-3623, 2003.

Gregg, W. W., Ginoux, P., Schopf, P.-S., and Casey, N. W.: Phytoplankton and iron: validation of a global three-dimensional ocean biogeochemical model, Deep-Sea Res. Pt. II, 50, 3143-3169, 2003.

Hamme, R. C., Webley, P. W., Crawford, W. R., Whitney, F. A., DeGrandpre, M. D., Emerson, S. R., Eriksen, C. C., Giesbrecht, K. E., Gower, J. F. R., Kavanaugh, M. T., Pena, M. A., Sabine, C. L., Batten, S. D., Coogan, L. A., Grundle, D. S., and Lockwood, D.: Volcanic ash fules anomalous plankton bloom in subarctic Northeast Pacific, Geophys. Res. Lett., 37, L19604, doi:10.1029/2010GL044629, 2010.

Jickells, T. D., An, Z. S., Andersen, K. K., Baker, A. R., Berggametti, G., Brooks, N., Cao, J. J., Boyd, W., Duce, R. A., Hunter, K. A., Kawahata, H., Kubilay, N., laRoche, J., Liss, P. S., Mahowald, N., Prospero, J. M., Ridgwell, A. J., Tegen, I., and Torres, R.: Global iron connections between desert dust, ocean biogeochemistry, and climate, Science, 308, 67-71, 2005.

Jones, M. T. and Gislason, S. R.: Rapid releases of metal salts and nutrients following the deposition of volcanic ash into aqueous environments, Geochim. Cosmochim. Ac., 72, 3661-3680, 2008.
Lancelot C., Hannon, E., Becquevort, S., C. Veth, C., and De Baar, H. J. W.: Modeling phytoplankton blooms and carbon export production in the Southern Ocean: dominant controls by light and iron in the Atlantic sector in Austral spring 1992, Deep-Sea Res. Pt. I, 47, 1621-1662, 2000.

Langmann, B.: Volcanic ash versus mineral dust: Atmospheric processing, and environmental and climate impacts, Int. J. Atmos. Sciences 2013, accepted, 2013.

Langmann, B., Zakšek, K., Hort, M., and Duggen, S.: Volcanic ash as fertiliser for the surface ocean, Atmos. Chem. Phys., 10, 38913899, doi:10.5194/acp-10-3891-2010, 2010a.

Langmann, B., Zakšek, K., and Hort, M.: Atmospheric distribution and removal of volcanic ash after the eruption of Kasatochi volcano: A regional model study, J. Geophys. Res., 115, D00L06, doi:10.1029/2009JD013298, 2010b.

Larkin, K.: Canada sees shock salmon glut, Nature News, available at http://www.nature.com/news/2010/100903/full/news.2010. 449.html, doi:10.1038/news.2010.449, 2010.

Lockwood, D., Quay, P. D., Kavanaugh, M. T., Juranek, L. W., and Feely, R. A.: High-resolution estimates of net community production and air-sea $\mathrm{CO}_{2}$ flux in the northeast Pacific, Global Biogeochem. Cy., 26, GB4010, doi:10.1029/2012GB004380, 2012.

Lorkowski, I. Pätsch, J., Moll, A., and Kühn, W.: Interannual variability of carbon fluxes in the North Sea from 1970 to 2006 - Competing effects of abiotic and biotic drivers on the gas exchange of $\mathrm{CO}_{2}$, Estuar. Coast. Shelf S., 100, 38-57, doi:10.1016/j.ecss.2011.11.037, 2012.

Marchetti, A., Sherry, N. D., Kiyosawa, H., Tsuda, A., and Harrison, P. J.: Phytoplankton processes during a mesoscale iron enrichment in the NE subarctic Pacific: Part I - Biomass and assemblage, Deep Sea Res. Pt. II, 53, 2095-2113, 2007.

Martin, J. H. and Fitzwater, S. E.: Iron deficiency limits phytoplankton growth in the north-east Pacific subarctic, Nature, 331, 341343, 1988.

McKinnell, S.: Challenges for the Kasatoshi volcano hypothesis as the cause of a large return of sockeye salmon (Oncorhynchus nerka) to the Fraser River in 2010, Fish. Oceanogr., accepted, doi:10.1111/fog.12023, 2013.

Moore, J. K., Doney, S. C., and Lindsay, K.: Upper ocean ecosystem dynamics and iron cycling in a global threedimensional model, Global Biogeochem. Cy., 18, GB4028, doi:10.1029/2004GB002220, 2004.

Olgun, N., Duggen, S., Croot, P. L., Delmelle, P., Dietze, H., Schacht, U. Oskarsson, N., Siebe, C., Auer, A., and GarbeSchoenber, D.: Surface ocean iron fertilization: The role of airborne volcanic ash from subduction zone and hot spot volcanoes and related iron fluxes into the Pacific Ocean, Global Biogeochem. Cy., 25, GB4001, doi:10.1029/2009GB003761, 2011.

Olgun, N., Duggen, S., Langmann, B., Hort, M., Waythomas, C. F., Hoffmann L., and Croot, P.: Geochemical evidence of oceanic iron fertilization by the Kasatochi volcanic eruption in 2008 and its impact on Pacific sockeye salmon, Mar. Ecol.-Prog. Ser., doi:10.3354/meps 10403, accepted, 2013.

Parsons, T. P. and Whitney, F. A.: Did volcanic ash from Kasatochi in 2008 contribute to a phenomenal increase in Fraser River sockeye salmon (Oncorhynchus nerka) in 2010?, Fish. Oceanogr., 21, 374-377, 2012.

Pätsch, J. and Kühn, W.: Nitrogen and carbon cycling in the North Sea and exchange with the North Atlantic - A model study. Part 
I. Nitrogen budget and fluxes, Cont. Shelf Res., 28, 767-787, 2008.

Sabine, C., Maenner, S., and Sutton, A.: High-resolution ocean and atmosphere $p \mathrm{CO}_{2}$ time-series measurements from mooring Papa_145W_50N, http://cdiac.esd.ornl.gov/ ftp/oceans/Moorings/Papa_145W_50N/, Carbon Dioxide Information Analysis Center, Oak Ridge National Laboratory, US Department of Energy, Oak Ridge, Tennessee. doi:10.3334/CDIAC/otg.TSM_Papa_145W_50N, 2010.

Wang, B., Michaelson, G., Ping, C.-L., Plumlee, G., and Hagemann, P.: Characterization of Pyroclastic Deposits and Pre-eruptive Soils following the 2008 Eruption of Kasatochi Island Volcano, Alaska, Arct. Antarct. Alp. Res., 42, 276-284, 2010.
Waythomas, C. F., Scott, W. E., Prejean, S. G., Schneider, D. J., Izbekov, P., and Nye, C. J.: The 7-8 August 2008 eruption of Kasatochi Volcano, central Aleutian Islands, Alaska, J. Geophys. Res., 115, B00B06, doi:10.1029/2010JB007437, 2010.

Whitney, F. A. and Freeland, H. J.: Variability in upper-ocean water properties in the NE Pacific Ocean, Deep-Sea Res. Pt. II, 46, 2351-2370, 1999.

Wilson, T. M., Cole, J. W., Steward, C., Cronin, S. J., and Jonston, D. M.: Ash storms: impact of wind-remobilised volcanic ash on rural communities and agriculture following the 1991 Hudson eruption, southern Patagonia, Chile, B. Volcanol., 73, 223-239, 2011. 